Vol. 7, No. 1, 2017

\title{
COMPARATIVE ANALYSIS OF TECHNICAL AND ECONOMIC CHARACTERISTICS OF GENERATOR SETS ON THE BASIS OF SYNCHRONOUS AND ASYNCHRONOUS GENERATORS
}

\author{
Mykola Mukha \\ National University “Odessa Maritime Academy", Ukraine \\ mykola_mukha@hotmail.com
}

\section{(c) Mukha M., 2017}

Abstract. The paper considers one of the ways of improving the technical and economic performance of ship autonomous electrical plants by using asynchronous generators with capacitor excitation instead of traditional generator sets with synchronous generators.

The following advantageous characteristics of an asynchronous generator in comparison with a synchronous one are defined. An asynchronous generator has smaller dimensions and weight as well as a simpler construction of the squirrel-cage rotor; there are neither multiturn rotor windings, nor sliding contacts and rotating semiconductor elements, nor current insulation on the rotor, which increases the limiting heating temperature and provides high limit speeds of the rotor. The higher efficiency of an asynchronous generator due to the small value of rotor resistance ensures its economy. The asynchronous generator has a sinusoidal waveform of the generated voltage, symmetry of the three-phase voltage at an uneven load. Rapid attenuation of currents in the case of loss of excitation ensures the safety of short-circuit modes for the asynchronous generator. The regulation of capacitive excitation of an asynchronous generator along the stator circuit allows the creation of high-speed and invariant voltage stabilization systems. Simplicity and safety of paralleling, absence of rotor oscillations at significant changes in the load ensure the stability of parallel operation in multimachine power plants.

Key words: electric power generation, synchronous and asynchronous generators, comparative technical and economic analysis.

\section{Introduction}

Ensuring the reliability and economy of electric power sources of autonomous power plants in industry and transport is a mandatory requirement. Currently, autonomous power plants use alternating three-phase alternators.

Traditionally and in most cases, synchronous generators (SG), the production of which is well established and their design is optimized, are used as a source of power, [1-3]. The contact version of the rotor, as the main disadvantage of synchronous generators, has been overcome by mastering the brushless technology of its excitation by installing a reversed synchronous machine and rotating rectifiers on the rotor (see Fig. 1, a). However, this complication of the rotor design has led to the SG complication and price rise. In addition, synchronous machines have a number of features and limitations of their use in stand-alone installations, which will be discussed below.

An alternative to using SG at autonomous power plants is utilizing asynchronous generators (AG) with a squirrel-cage rotor (see Fig. 1, b), [4-6], which have practically displaced the $\mathrm{SG}$ in the windpower engineering.

\section{Comparative technical and economic analysis}

The asynchronous machine has a simple design of the squirrel-cage rotor with a diecast aluminum winding of "squirrel-cage" type with closed slots. This winding design allows a significant decrease in the air gap and reduction of losses along the path of the main magnetizing flux that make it possible to reduce the geometric dimensions of the rotor and the machine as a whole. The absence of sliding contacts and rotating semiconductor elements, replacement of insulated copper winding with cast aluminum make it possible to raise the operating temperature of the rotor and increase its maximum speed, which expands the operational range of using the asynchronous machine in comparison with the synchronous one.

Thus, with the same mechanical characteristics and degree of protection, the asynchronous machine will have less weight and size. According to the designers of electrical machines, the weight-size parameters of asynchronous machines will be 1.4 times less than synchronous ones with slip rings on the rotor $[5,6]$.

A small resistance of the asynchronous machine rotor and a smaller air gap determine the higher efficiency $\eta$ of the AG compared to the SG, which ensures greater economy of the $\mathrm{AG},[4,5]$.

Fig. 2 shows the dependence of efficiency $(\eta)$ of both a number of synchronous and asynchronous 
generators produced by different manufacturers and the asynchronous machines of AIR series on their nominal active power $\mathrm{P}_{\mathrm{g}}[1-4]$.

The AG efficiency is about $2 \%$ higher than that of the SG with the same power, which makes its use more economical. For example, the annual savings from replacing a ship synchronous generator with $1 \mathrm{MW}$ asynchronous one will be about 12,000 USD.

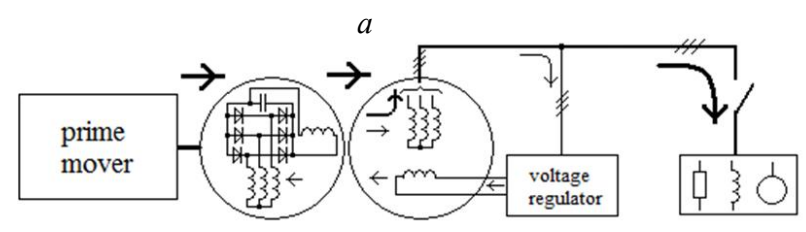

$b$

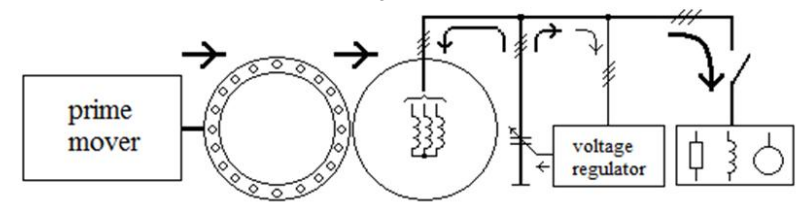

Fig. 1. Stand-alone electrical installations with brushless synchronous (a) and asynchronous (b) generators.

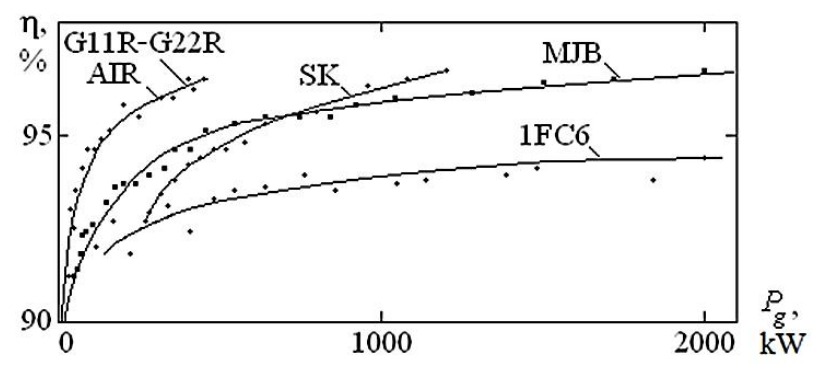

Fig. 2. Efficiency of generators

The main reason for $A G$ not being used in autonomous power plants is the technical need for using power capacitors as an additional source of reactive power to excite and control the AG voltage, Fig. 1, $b$.

At present, there have been changes in the technology of producing AC capacitors, significantly reducing both their cost and weight-size parameters. So, polypropylene capacitors basically have a thin polymer film with aluminum spraying of electrodes, i.e. cheap and light components. The specific gravity of such capacitors is approximately equal to $0.1 \mathrm{~kg} / \mathrm{kVA}$, which are 50-100 times less than that of electric machines [1-4]. Besides, the cost of modern capacitors is an order of magnitude lower than the price of generators.

The reduction in the price of cosine capacitors and thyristors has currently stimulated the production of controlled reactive-power compensating installations with semiconductor switching of the capacitors and their wide application in industry and transport. Technologically, such installations differ from AG excitation systems solely by controllers.

AG and SG are significantly different in the design of the rotor, as well as in the method of excitation and control of the generated voltage (see Fig. 1).

In $\mathrm{SG}$, the excitation is caused by the rotor circuit, and the electromagnetic field of the generator is created and changed by the excitation winding by regulating the current in it. A SG voltage regulator changes the current in the excitation winding as a function of deviation of stator voltage from the set value. As a rule, the analogue voltage regulator of a synchronous generator realizes the proportional or proportional-integral control law. To reduce the control power, it is necessary that the excitation winding be multiturn to create the required field at a small current. However, due to this, the inductance and the time constant of the excitation winding substantially increase, which reduces the regulation rapidity of the $\mathrm{SG}$.

To increase the speed of the voltage regulation system, the SG controller has boosting capabilities, i.e. the maximum value of the excitation voltage in the transient process allows a 5-8 multiple of the nominal value.

In $A G$, the excitation is provided due to the oscillatory process of energy exchange between the inductance of the machine and the excitation capacitance connected to the stator circuits of the AG. The AG voltage will depend on the magnetization curve of the machine, the speed of rotation, the load and the magnitude of the capacitive excitation current $[6,7]$.

The AG excitation regulator changes the capacitive current of the capacitors as a function of the deviation of its voltage from the nominal value. A load current and a capacitive excitation current flow along one stator circuit of the generator, which allows almost instantaneous compensation of the generator's response to the load with a capacitive current. The only problem to be solved is connected with the rapid measurement of the regulated quantity and the choice of the optimal control law. The regulation of the $\mathrm{AG}$ excitation in the stator circuit makes it possible to create high-speed and invariant voltage stabilization systems $[8,9]$.

If voltage measurement and capacitor switching are performed within one period of the generated current, then the transient process of voltage restoration of the AG after load switching ends in $2-3$ periods, i.e. in 0.04-0.06 s. At the same time, the minimum time of the transient process in the SG is 0.5 s, Fig. 3, 4 [10]. 


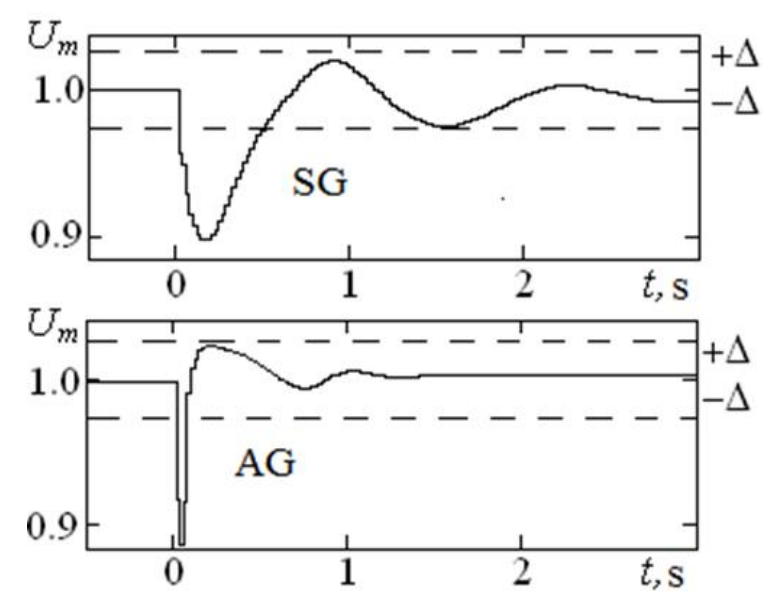

Fig. 3. Transient process of voltage recovery of the $S G$ and $A G$ after switching on $50 \%$ of the rated load with a power factor $0.8 ; \Delta=0,02 U_{m}$.

Transient processes of the synchronous and asynchronous electric power installation are illustrated in Fig. 4. The magnitude of the dynamic dip of the voltage of an asynchronous installation is two to three times less than that of a synchronous one. The time of transition process is very different. In the synchronous generator, it is $0.5-0.6 \mathrm{~s}$, and asynchronous - does not exceed $0.05 \mathrm{~s}$, i.e. $2-3$ periods of the voltage generated.
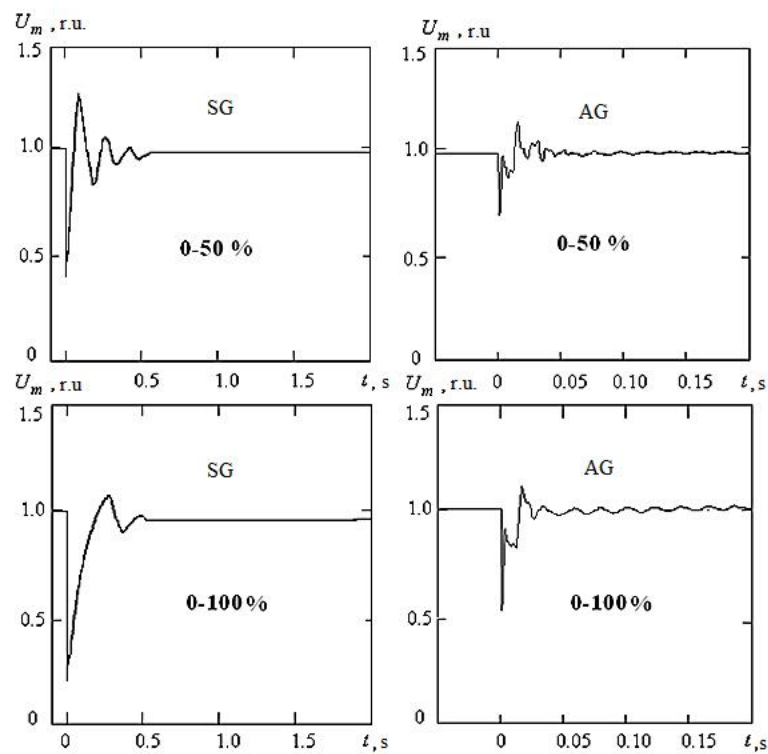

Fig. 4. Transient processes of switching on $50 \%$ and $100 \%$ active-inductive loads to synchronous and asynchronous power plant.

The processes occurring in the voltage control channel are significantly different. The inertia of the excitation circuit of the synchronous generator does not allow a quick compensation of the demagnetizing effect of the switching load, which delays the process of restoration of the generator voltage. In an asynchronous generator, the voltage control is performed in the stator circuit, i.e. in the same place where the load changes.
This enables the effect of the load to be compensated for almost instantly, over the period of voltage generation. The electrical installation with optimum adjustment parameters of the AG excitation regulator makes it almost invariant to the load.

The difference in the excitation systems of SG and AG has an effect on the overload capacity of the generators and their response to short circuits. With a double (or more) overload and a limited capacity of the AG excitation, the voltage sharply drops to zero, which does not occur in the SG when overloaded, so it needs protecting from such emergency modes. In the case of a short circuit, the excitation capacitance is shunted, and the $\mathrm{AG}$ is rapidly deexcited due to the small time constants of scattering loops of the generator.

Fig. 5 shows the processes of changing the phase current and voltage with a five times increase in the load conductivity.
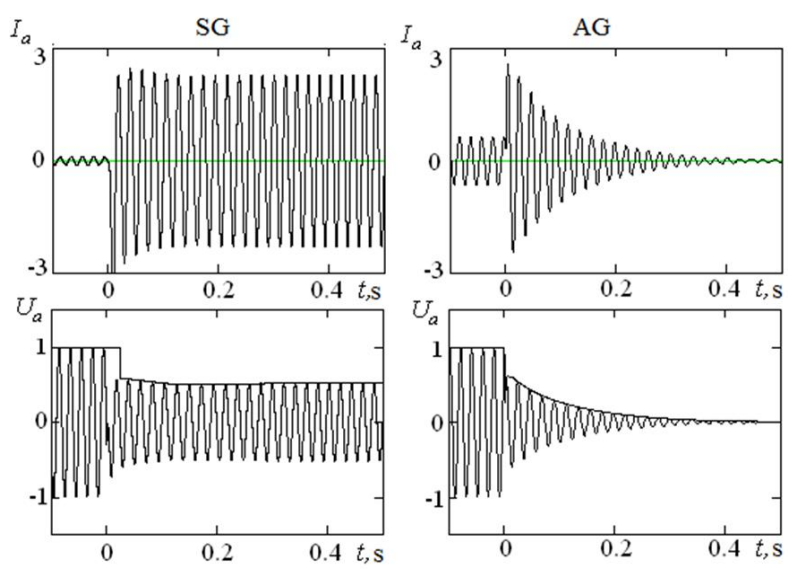

Fig. 5. Short-circuit processes in $S G$ and $A G$.

Thus, the short circuit mode for the AG is safe. In this case, the selectivity of protection against short circuits in the branched electrical network of the AG must be provided in 2-3 current periods, [6].

It should be noted that the limitation of the overload capability of the AG is proportional to the magnitude of the excitation capacitance. If the generator is calculated for a nominal power factor $\cos \varphi=0.8$, it is possible to directly start an induction motor with a power of up to $30 \%$ of the generator's power. If the excitation capacitance of the AG is not limited, it is possible to start the motor commensurate with the power generator, [7].

By virtue of the filtering properties of capacitors, the asynchronous generator has a sinusoidal waveform of the generated voltage with a low harmonic content [7] and the symmetry of three-phase voltage with the load being distributed unevenly [6].

The vector of the electromagnetic field of the SG is rigidly attached to the geometric axis of the excitation winding. An increase in the load angle (between the field 
and the winding axis) by more than 90 degrees leads to an emergency mode of loss of synchronism. The mode of "swinging the SG rotor" is especially dangerous when paralleling and when the load is redistributed during the parallel operation. In this case, loss of synchronism leads, as a rule, to de-energization, [11].

Unlike the SG, the technological presence of sliding the AG rotor relative to the field significantly increases the stability of the system of parallelly operating generators. At the same time, there are no restrictions on the number of generators operating in the same network, which is confirmed by the experience of using AG in wind power.

The mode of AG parallelling is not dangerous for the generators, and if the phases do not coincide up to 90 degrees, the voltage dip does not exceed $30 \%$. At the same time, when the phase difference of the connected SGs is more than 60 degrees, the voltage drop exceeds $50 \%$.

Fig. 6 shows the synchronization processes of the moments, rotation frequencies and the establishment of generator voltages with the phase difference when switching on at 90 degrees. The synchronization moments $\mathrm{M}_{1}, \mathrm{M}_{2}$ reach 5 nominal values, and the frequencies $\omega_{1}, \omega_{2}$ deviate by $5-7 \%$. The attenuation of the moments and frequencies oscillations with the SG being included in the parallel continues for $0.7 \mathrm{~s}$, and at the similar inclusion of the AG $-0.2 \mathrm{~s}$. The dynamic deviations of the modulus of the voltage vector $U_{m}$ of the SG are $+50--80 \%$, the process of voltage establishment lasts $0.35 \mathrm{~s}$. When the AG is switched on, the voltage is deflected by $+20--30 \%$ within $0.2 \mathrm{~s}$.
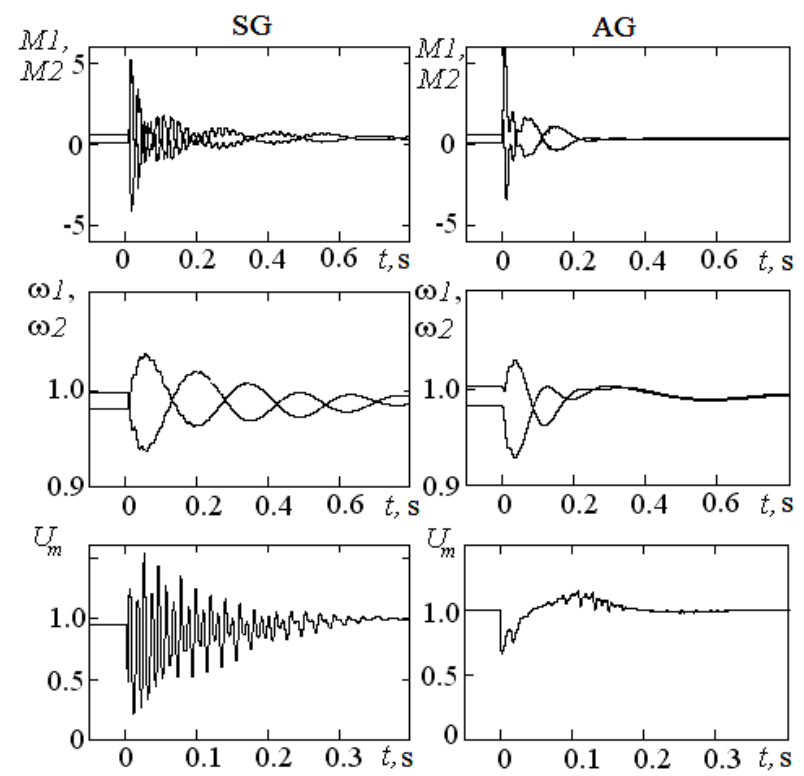

Fig. 6. Processes of generators parallelling with a phase difference of 90 degrees.

If another non-excited $\mathrm{AG}$, which rotates at a synchronous speed, are connected in parallel with the $\mathrm{AG}$, the synchronization will occur with a double moment, with a frequency deviation of $3 \%$ within $0.2 \mathrm{~s}$, a (the) voltage drop will be $50 \%$ within $0.15 \mathrm{~s}$.

\section{Conclusions}

An asynchronous generator has smaller dimensions and weight, simpler construction of the short-circuited rotor of the generator, no multiturn (multi-coil) rotor windings, sliding contacts and rotating semiconductor elements, no current insulation on the rotor, which increases the maximum heating temperature and provides high limit speeds of the rotor.

The higher efficiency of the AG due to the small value of the (active) rotor resistance ensures its economy.

The asynchronous generator has a sinusoidal waveform of the generated voltage and a symmetrical three-phase voltage at an uneven load.

The rapid attenuation of scattering currents and loss of excitation ensures the safety of short-circuit modes for the AG generator.

The regulation of the capacitive excitation of the AG in the stator circuit makes it possible to create both expeditious and invariant voltage stabilization systems.

Simplicity and safety of paralleling, absence of rotor oscillations at significant changes in the load ensure stability of parallel operation in multi-generator power plants.

The advantages of AG confirm the advisability of wide implementation and application of asynchronous generator sets in autonomous power stations to increase their reliability and reduce the cost of electricity.

\section{References}

[1] Brushless Constant-Voltage Synchronous Alternators 1FC. Low-Voltage for shipboard and industrial use, Pula, Croatia: Uljanik TESU d.d., 2007.

[2] MJB. Data Sheets Three-phase Synchronous Generators. Power generation, 160-630 frame sizes Industrial application, Arzignano (VI), Italy: Marelli Motori S.p.A., 2013.

[3] Synchronous Alternators Sincro. SKM Brushless marine alternators, Terrey Hills, Australia, 2013. http://www.sincro.com.au.

[4] Three-phase Asynchronous Generators. G11R$G 22 R$, Langenhagen, Germany: VEM motors $\mathrm{GmbH}, 2015$.

[5] V. Radin and V. Vinokurov, "The use of asynchronous generators as autonomous alternating current sources", Electrical Engineering, no. 8, pp. 17-20, Moscow, Russia, 1967. (Russian)

[6] L. Vishnevskiy and A. Pass, Control systems for asynchronous generator sets. Kyiv-Odessa, Ukraine: Lybid, 1990. (Russian)

[7] L. Vishnevskiy, "Theory and methods of calculation of control systems and operational 
modes of ship electrical installations with asynchronous generators," Doctor of Engineering dissertation, St. Petersburg, Russia, 1991. (Russian)

[8] L. Vishnevskiy, "Analysis of the quality of discrete voltage control laws for generator sets", Elektromashynobuduvannia ta elektroustatkuvannia, vol. 55, pp. 46-52, Kyiv, Ukraine: Technique, 2000. (Russian)

[9] L. Vishnevskiy, M. Mukha, and A. Veretennik, "Calculation of voltages in electrical installations with impulse regulators", Automation of ship technical means, vol. 8, pp. 8-15, Odessa, Ukraine: OSMA, 2003. (Russian)

[10] L. Vishnevskiy, M. Mukha, and A. Veretennik, "Computer modeling of ship auxiliary electrical installations", Ship power plants, no 6, pp. 23-30, Odessa, Ukraine: OSMA, 2001. (Russian)

[11] L. Vishnevskiy, M. Mukha, and Dao Min Kuan, Voltage control of autonomous asynchronous generators, the monograph, Odessa, Ukraine: NU "OMA", 2016. (Russian)

\section{ПОРІВНЯЛЬНИЙ АНАЛІЗ ТЕХНІКО- ЕКОНОМІЧНИХ ХАРАКТЕРИСТИК ГЕНЕРАТОРНИХ УСТАНОВОК НА ОСНОВІ СИНХРОННОГО ТА АСИНХРОННОГО ГЕНЕРАТОРА}

\footnotetext{
Микола Муха

Розглянуто один зі способів підвищення технікоекономічних показників суднових автономних електроустановок через застосування асинхронних генераторів 3 конденсаторними збудженнями замість традиційних генераторних агрегатів із синхронними генераторами.

Подано результати порівняльного аналізу технікоекономічних характеристик генераторних агрегатів на основі синхронного та асинхронного генератора. Визначені такі переважні характеристики асинхронного генератора перед синхронним: асинхронний генератор має
}

менші розміри та масу, простішу конструкція короткозамкнутого ротора генератора, відсутні багатожильні роторні обмотки, ковзаючі контакти i поворотні напівпровідникові елементи, відсутня струмова ізоляція на роторі, що підвищує граничну температуру нагріву i забезпечує високі граничні швидкості обертання ротора.

Вищий ККД асинхронного генератора внаслідок малого значення активного опору ротора забезпечує його економічність. Асинхронний генератор має синусоїдальну форму кривої напруги, симетричну трифазну напругу за нерівномірного навантаження.

Швидке загасання струмів розсіювання за втрати збудження гарантує безпеку режимів коротких замикань для асинхронного генератора.

Регулювання ємнісного збудження асинхронного генератора в колі статора дає змогу створювати швидкодіючі та інваріантні системи стабілізації напруги.

Простота і безпека включення в паралельну роботу, відсутність коливань ротора за значних змін навантаження забезпечують стійкість паралельної роботи в багатоагрегатних електростанціях. Указані переваги асинхронних генераторів перед синхронними підтверджують доцільність широкого впровадження асинхронних генераторних установок в автономних електростанціях з метою підвищення їхньої надійності та зниження вартості електроенергії.

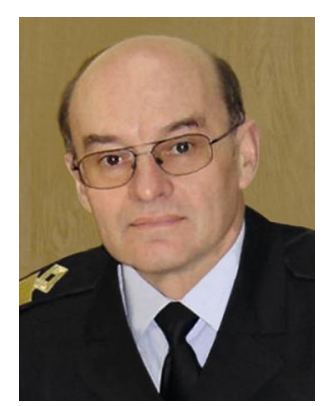

Mykola Mukha - Associate Professor, Ph.D., Member of IMarEST (The Institute of Marine Engineering, Science and Technology) in Chartered Engineer status, London, England, since 1996, First class Ship's Senior Electro-Technical Officer, National University "Odessa maritime academy"

(NUOMA), Ukraine. Area of scientific interests: ship automated electric power systems, compensation of reactive power in autonomous power-generating plants. His research findings have been published in more than 50 scientific papers including 7 patents. 